\title{
Analytical Method Development Using Central Composite Design for Estimation of Lamotrigine in Lipid Nanoformulation
}

\author{
PUJA K GANGURDE ${ }^{1}$, NAVYA AJITKUMAR BHASKARAN ${ }^{1}$, RUCHI VERMA ${ }^{2}$, \\ JOBIN JOSE ${ }^{3}$, LALIT KUMAR ${ }^{1, *}$ \\ ${ }^{1}$ Department of Pharmaceutics, ${ }^{2}$ Department of Pharmaceutical Chemistry, Manipal College of Pharmaceutical Sciences, \\ Manipal Academy of Higher Education, Manipal 576 104, Udupi, Karnataka, India. \\ ${ }^{3}$ Department of Pharmaceutics, Nitte Gulabi Shetty Memorial Institute of Pharmaceutical Sciences, NITTE Deemed to be \\ University, Paneer, Deralakatte 575 018, Mangalore, India.
}

\begin{abstract}
Abstact. Objective of this study was to develop and validate HPLC-UV method for detection of LTG in lipid nanoformulations. HPLC-UV method was developed according to ICH Q2(RI) guidelines. Central composite design was used effectively to optimize and study the effect of buffer strength, flow rate, $p H$ of buffer and mobile phase composition on responses such as tailing factor, peak area, retention time and number of theoretical plates. The $30 \mathrm{mM}$ ammonium formate buffer and acetonitrile (in the ratio 65:35\%v/v) was used as mobile phase in the study. The mobile phase was delivered at the flow rate of $1.0 \mathrm{~mL} / \mathrm{min}$. The detection of buffer was performed at $256 \mathrm{~nm}$ using UV detector. The drug entrapment of prepared formulation was also determined using developed HPLC method. Retention time of lamotrigine was found to be $3.844 \mathrm{~min}$. The coefficient of determination $\left(r^{2}\right)$ value from linearity was found to be 0.9982. Percent relative standard deviation value of precision was found to be within the acceptable range. The estimated LOD and LOQ were found to be $9.07 \mathrm{ng} / \mathrm{mL}$ and 27.48 $n g / m L$, respectively. Drug entrapment of prepared lipid nanoformulation was found to be $73.44 \pm$ $6.65 \%$. The results conclude that the developed analytical method is simple, precise, sensitive, fast and reproducible. Applications of developed method for determination of drug entrapment in prepared lipid nanoformulation confirmed that the developed analytical method is suitable for estimation of lamotrigine in lipid nanoformulations.
\end{abstract}

Keywords: Lamotrigine, RP-HPLC-UV, central composite design, lipid nanoformulations, design of experiments.

\section{Introduction}

Lamotrigine is a phenyl triazine derivative, it was approved by United States Food and Drug Administration (USFDA) in 1994 for the treatment of epilepsy [1,2]. This is widely used to treat generalized clonic-tonic seizures, partial seizures and Lennox-Gastaut syndrome. Lamotrigine is also used to treat bipolar I disorder in patients [2-5].

In market, lamotrigine is available as a tablet, but the problem with conventional tablets of lamotrigine is its lack of concentration in the brain after oral administration due to its low permeability through the blood brain barrier (BBB). As the lamotrigine is not able to cross BBB which results in requirement of higher dose to achieve therapeutic effect. Furthermore, if higher dose is given by orally it causes increase in concentration of lamotrigine in systemic blood which results in hypersensitive reactions, rashes, Stevens-Johnson syndrome, epidermal necrosis, etc [1-4].

There is a need of advanced drug delivery to avoid above mentioned side effects. Nanoformulation is a promising approach to solve this problem. There are several analytical methods are reported for quantification of lamotrigine in tablets and biological fluids [4,6]. Some of the methods are enlisted in Table 1.

\footnotetext{
$\overline{\text { *mail: lalit.kumar@manipal.edu; lk.kundlas@gmail.com }}$
} 
Table 1. List of HPLC methods available for estimation of lamotrigine

\begin{tabular}{|c|c|c|c|c|c|c|}
\hline $\begin{array}{l}\text { S. } \\
\text { No. }\end{array}$ & Stationary Phase & Mobile Phase & $\begin{array}{l}\text { Detection } \\
\text { wavelength } \\
(\mathbf{n m})\end{array}$ & $\begin{array}{l}\text { Lamotrigine } \\
\text { Sample }\end{array}$ & LOD/ LOQ & Ref \\
\hline 1. & $\begin{array}{l}\mathrm{C}_{18} \mu \text {-Bondapack column } \\
\quad(250 \mathrm{~mm} \times 4.6 \mathrm{~mm})\end{array}$ & $\begin{array}{c}\text { Acetonitrile- monobasic } \\
\text { potassium phosphate } \\
(35: 65 \mathrm{v} / \mathrm{v})\end{array}$ & 210 & Tablet & $\begin{array}{c}0.01 \mu \mathrm{g} / \mathrm{mL} \\
\text { and } 0.05 \\
\mu \mathrm{g} / \mathrm{mL} \\
\end{array}$ & [4] \\
\hline 2. & $\begin{array}{l}\mathrm{RP} \mathrm{C}_{18}(55 \mathrm{~mm} \times 4 \mathrm{~mm} \\
\text { and } 3 \mu \mathrm{m} \text { particle size })\end{array}$ & $\begin{array}{c}\text { Water-methanol- } \\
\text { acetonitrile-TEA } \\
(68.7: 25: 6: 0.3 \mathrm{v} / \mathrm{v} / \mathrm{v} / \mathrm{v})\end{array}$ & 237 & Human Plasma & $\begin{array}{c}0.02 \mu \mathrm{g} / \mathrm{mL} \\
\text { and } 0.10 \\
\mu \mathrm{g} / \mathrm{mL}\end{array}$ & [7] \\
\hline 3. & $\begin{array}{c}\mathrm{C}_{18}(250 \mathrm{~mm} \times 4.6 \mathrm{~mm} \\
\text { i.d., } 5 \mu \mathrm{m})\end{array}$ & $\begin{array}{c}0.05 \mathrm{M} \text { Ammonium } \\
\text { phosphate-acetonitrile } \\
(68: 32, \mathrm{v} / \mathrm{v}, \mathrm{pH} 2.68)\end{array}$ & 265 & Tablet & ---- & [8] \\
\hline 4. & $\begin{array}{c}\mathrm{RP} \mathrm{C}_{18} \\
\text { (length } 250 \mathrm{~mm} \text { and inner } \\
\text { diameter } 4.6 \mu \mathrm{m} \text { ) }\end{array}$ & $\begin{array}{c}0.1 \text { M Dihydrogen } \\
\text { phosphate buffer- } \\
\text { acetonitrile }(75 / 25 \mathrm{v} / \mathrm{v}) \\
\end{array}$ & 210 & Human Plasma & $\begin{array}{c}0.07 \mu \mathrm{g} / \mathrm{mL} \\
\text { and } 0.21 \\
\mu \mathrm{g} / \mathrm{mL} \\
\end{array}$ & [9] \\
\hline 5. & $3 \mathrm{C}_{18}(15 \mathrm{~cm} \times 0.46 \mathrm{~cm})$ & $\begin{array}{l}\text { Methanol- Acetonitrile-25 } \\
\text { mM Phosphate buffer } \\
(14.5: 19.5: 66 \mathrm{v} / \mathrm{v} / \mathrm{v})\end{array}$ & 275 & Human serum & $\begin{array}{c}0.008 \mu \mathrm{g} / \mathrm{mL} \\
\text { and } 0.014 \\
\mu \mathrm{g} / \mathrm{mL}\end{array}$ & [10] \\
\hline 6. & $\begin{array}{c}\mathrm{C}_{18}(25 \mathrm{~cm} \times 4.6 \mathrm{~mm} \text { and } \\
\text { i.d., } 5 \mu \mathrm{m})\end{array}$ & $\begin{array}{c}\text { Methanol- } 0.05 \mathrm{M} \\
\text { potassium dihydrogen } \\
\text { orthophosphate (65: } 35 \\
\mathrm{v} / \mathrm{v}) \\
\end{array}$ & 270 & Tablet & $\begin{array}{c}15 \mathrm{ng} / \mathrm{mL} \text { and } \\
5 \mathrm{ng} / \mathrm{mL}\end{array}$ & [11] \\
\hline 7. & $\begin{array}{c}\text { LC-18 } \\
(150 \times 4.6 \mathrm{~mm})\end{array}$ & $\begin{array}{c}\text { 0.1 M Potassium } \\
\text { dihydrogen } \\
\text { orthophosphate solution- } \\
\text { methanol -triethylamine, } \\
(560: 435: 0.1, \mathrm{v} / \mathrm{v} / \mathrm{v})\end{array}$ & 306 & Human Plasma & $\begin{array}{c}0.19 \text { and } 0.58 \\
\mathrm{mmol} / \mathrm{L}\end{array}$ & [12] \\
\hline 8. & $\begin{array}{c}\mathrm{C}_{18}(150 \mathrm{~mm} 4.6 \mathrm{~mm} \text { and } \\
\text { equivalent } 5 \mu \mathrm{m})\end{array}$ & $\begin{array}{c}\text { Acetonitrile }(\mathrm{ACN}) \\
\text { Phosphate buffer }(0.05 \\
\text { mol })(20: 80 \mathrm{v} / \mathrm{v})\end{array}$ & 270 & Tablet & ---- & {$[13]$} \\
\hline 9. & $\begin{array}{c}\mathrm{RP} \mathrm{C}_{18} \\
(10 \mu \mathrm{m}, 250 \mathrm{~mm} \times 4.6 \\
\mathrm{mm})\end{array}$ & $\begin{array}{c}\text { Acetonitrile- methanol - } \\
0.01 \mathrm{M} \text { potassium } \\
\text { orthophosphate }(\mathrm{pH} \\
6.7+/-0.1)(30: 20: 50 \\
\mathrm{v} / \mathrm{v} / \mathrm{v}) \\
\end{array}$ & 275 & Tablet & ---- & [14] \\
\hline 10. & $\begin{array}{l}\text { RP } 18 \text { Lichrocart-Merck } \\
(125 \times 4 \text { mm I.D., } 5 \mu \mathrm{m} \\
\text { particles })\end{array}$ & $\begin{array}{c}0.01 \mathrm{M} \text { potassium } \\
\text { phosphate buffer } \mathrm{pH} 6.5- \\
\text { acetonitrile - methanol } \\
(65: 18: 17 \mathrm{v} / \mathrm{v} / \mathrm{v})\end{array}$ & 220 & Plasma & $\begin{array}{l}0.1 \mu \mathrm{g} / \mathrm{mL} \\
\text { (LOQ) }\end{array}$ & {$[15]$} \\
\hline
\end{tabular}

All methods listed in Table 1 are for estimation of the drug in tablets or in biological fluids and most of them have used phosphate buffer as a mobile phase, but that reduces the high performance liquid chromatography (HPLC) column life [16]. Furthermore, methods are not reported for detection of LTG in lipid nanoformulations. Hence, there is a need of developing an effective method for the detection of lamotrigine in nanoformulation. The purpose of present study was to develop and validate analytical method using design of experiments (DoE) for the detection of lamotrigine in nanoformulation by HPLC with UV detector.

Optimisation of chromatographic conditions is a very important step and the optimisation of HPLC chromatographic conditions is very complex process which consists of various factors, like mobile phase composition, $p \mathrm{H}$ of mobile phase, flow rate, strength of buffer, etc.

Conventional method of optimization is based on 'one factor at a time (OFAT)'. In this method, we study the effect of a single factor on response. It causes poor optimization as other factors are maintained at constant levels. We cannot study the interactive effect of variables. Also, it is associated with several disadvantages like this method is not reproducible, expensive and time consuming.

DoE is most efficient in studying interaction between variables, it is very economical and less timeconsuming approach for optimization of variables. Due to its numerous advantages, now it is widely used by researchers [16-19]. 
Central composite design (CCD) is most widely used, because of its high efficiency and robustness in terms of the number of trials. With the help of CCD, we can study efficiently the interaction between variables. Purpose of this study was to optimize chromatographic conditions by investigating the effect of various variables on responses with the help of CCD.

\section{Materials and methods Instrumentation}

The liquid chromatographic system used was HPLC (LC-2010CHT Shimadzu Corporation Ltd., Tokyo) with UV detector and LC solution 5.57. The chromatographic separation was performed on HyperClone (Phenomenex $\left.{ }^{\circledR}\right) \mathrm{C}_{18}(250 \mathrm{~mm} \times 4.6 \mathrm{~mm}$ i.d, $5 \mu \mathrm{m}$, BDS $130 \AA$ A) with security guard precolumn (Phenomenex $\left.{ }^{\circledR}\right) \mathrm{C}_{18}(4.0 \times 3.0 \mathrm{~mm}$ i.d). Millipore glass filter was used for the filtration of mobile phase. Bath sonicator (Ultrasonic cleaner-15L, Equitron-Medica Instrument Mfg. Co.,

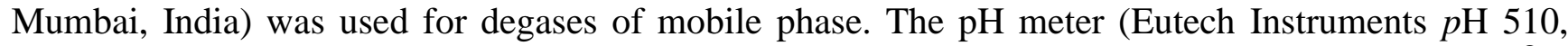
Van London Co., USA) with a glass electrode was used to measure the $\mathrm{pH}$ of buffer. The Direct- $\mathrm{Q}^{\circledR} 3$ system (Millipore Corporation, Billerica, MA, USA) was used for water purification.

\section{Chemicals and solvents}

Lamotrigine was obtained as a gift sample from Dr. Reddy's Laboratories, Hyderabad. The HPLC grade acetonitrile was procured from Merck Ltd., Mumbai, India. Formic acid was obtained from Spectrochem Pvt. Ltd. Mumbai, India. Ammonium formate was procured from Sisco Research Laboratories Pvt. Ltd. Mumbai, India.

\section{Preparation of solutions \\ Preparation of buffer}

Ammonium formate buffer $(30.0 \mathrm{mM})$ was prepared by dissolving $1.89 \mathrm{~g}$ of ammonium formate in 1.0 L milli Q water and buffer $\mathrm{pH}$ was attuned to 3.6 using formic acid. Prepared buffer was passed through a membrane filter with pore size $0.22 \mu$ [16].

\section{Preparation of mobile phase}

Mobile phase was consisting of acetonitrile and ammonium formate buffer. As ammonium formate is highly volatile than phosphate buffer hence there are less chance of precipitation of buffer in HPLC column and HPLC tubing [16,20].

\section{Preparation of stock solution of drug}

To prepare the stock solution of LTG, $100 \mu \mathrm{g} / \mathrm{mL}$ was dissolved in $2 \mathrm{~mL}$ of methanol and then the volume was made up with mobile phase to $100 \mathrm{~mL}$. Further the dilutions were made with mobile phase to prepare the working concentrations.

\section{Optimization and development of HPLC method}

Strength of buffer, buffer $p \mathrm{H}$, flow rate and mobile phase composition plays an imperative role in HPLC chromatogram. These can affect the peak area, retention time, tailing factor, number of theoretical plates, and peak resolution. Among all the factors two factors i.e. strength of $p \mathrm{H}$ and $p \mathrm{H}$ of buffer are the prime factors. Hence, in the present study few preliminary trials were taken to understand the effect of buffer strength and buffer $\mathrm{pH}$ by keeping other conditions constant. Further, the strength of buffer (A), $p \mathrm{H}$ of buffer $(\mathrm{B})$, flow rate $(\mathrm{C})$ and mobile phase ratio (D) were optimized by applying central composite design $(C C D)$ for tailing factor $\left(R_{1}\right)$, peak area $\left(R_{2}\right)$, retention time $\left(R_{3}\right)$ and number of theoretical plates $\left(\mathrm{R}_{4}\right)$.

For present study Design Expert ${ }^{\circledR}$ software (v.9.0.5.1) was used. Two levels were entered in software by selecting central composite design for these four variables (strength of buffer, $p \mathrm{H}$ of 
buffer, flow rate and mobile phase) as shown in Table 2 and software has suggested total 30 experiments to be performed as shown in Table 3.

Table 2. List of factors and levels

\begin{tabular}{|l|l|l|}
\hline \multirow{2}{*}{ Factors } & Levels \\
\cline { 2 - 3 } & $\mathbf{- 1}$ & $\mathbf{+ 1}$ \\
\hline Strength of buffer $(\mathrm{mM})$ & 25 & 35 \\
\hline Flow rate (mL/min) & 0.9 & 1.1 \\
\hline pH of buffer & 3.4 & 3.8 \\
\hline Mobile phase ratio (\%v/v) & $25: 75$ & $35: 65$ \\
\hline
\end{tabular}

Table 3. Composition of trials suggested by central composite design

\begin{tabular}{|c|c|c|c|c|c|c|c|c|}
\hline $\begin{array}{c}\text { Experi } \\
\text { ment } \\
\text { no }\end{array}$ & $\begin{array}{c}\text { Strength } \\
\text { of } \\
\text { buffer } \\
\text { (mM) }\end{array}$ & $\begin{array}{l}\text { pH of } \\
\text { Buffer }\end{array}$ & $\begin{array}{c}\text { Flow } \\
\text { rate } \\
\text { (mL/min) }\end{array}$ & $\begin{array}{c}\text { Mobile } \\
\text { phase } \\
\text { ratio } \\
(\% \mathrm{v} / \mathrm{v})\end{array}$ & $\begin{array}{l}\text { Retention } \\
\text { time (min) }\end{array}$ & $\begin{array}{l}\text { Peak area } \\
(\mathbf{u V})\end{array}$ & $\begin{array}{l}\text { Tailing } \\
\text { factor }\end{array}$ & NTP \\
\hline 1 & 35.00 & 3.80 & 0.90 & $25: 75$ & 7.021 & 355786 & 1.539 & 6328 \\
\hline 2 & 35.00 & 3.40 & 1.10 & $25: 75$ & 5.585 & 292331 & 1.404 & 6260 \\
\hline 3 & 25.00 & 3.80 & 1.10 & $25: 75$ & 6.118 & 292775 & 1.587 & 5650 \\
\hline 4 & 25.00 & 3.40 & 0.90 & $25: 75$ & 6.961 & 358881 & 1.486 & 6736 \\
\hline 5 & 23.00 & 3.60 & 1.00 & $25: 75$ & 6.377 & 316839 & 1.541 & 5942 \\
\hline 6 & 37.00 & 3.60 & 1.00 & $25: 75$ & 6.477 & 322345 & 1.460 & 6307 \\
\hline 7 & 30.00 & 3.30 & 1.00 & $25: 75$ & 6.175 & 316724 & 1.401 & 6680 \\
\hline 8 & 30.00 & 3.90 & 1.00 & $25: 75$ & 6.367 & 314751 & 1.563 & 5803 \\
\hline 9 & 30.00 & 3.60 & 0.86 & $25: 75$ & 7.555 & 374463 & 1.516 & 6641 \\
\hline 10 & 30.00 & 3.60 & 1.14 & $25: 75$ & 5.753 & 277600 & 1.466 & 6016 \\
\hline 11 & 30.00 & 3.60 & 1.00 & $25: 75$ & 6.495 & 321334 & 1.506 & 6165 \\
\hline 12 & 30.00 & 3.60 & 1.00 & $25: 75$ & 6.508 & 321359 & 1.497 & 6208 \\
\hline 13 & 30.00 & 3.60 & 1.00 & $25: 75$ & 6.512 & 322796 & 1.510 & 6193 \\
\hline 14 & 30.00 & 3.60 & 1.00 & $25: 75$ & 6.504 & 321067 & 1.503 & 6181 \\
\hline 15 & 30.00 & 3.60 & 1.00 & $25: 75$ & 6.510 & 322758 & 1.499 & 6210 \\
\hline 16 & 35.00 & 3.80 & 0.90 & $35: 65$ & 4.325 & 354494 & 1.516 & 5273 \\
\hline 17 & 35.00 & 3.40 & 1.10 & $35: 65$ & 3.461 & 295374 & 1.404 & 5150 \\
\hline 18 & 25.00 & 3.80 & 1.10 & $35: 65$ & 3.661 & 291044 & 1.535 & 4650 \\
\hline 19 & 25.00 & 3.40 & 0.90 & $35: 65$ & 4.319 & 362085 & 1.473 & 5586 \\
\hline 20 & 23.00 & 3.60 & 1.00 & $35: 65$ & 3.919 & 322291 & 1.523 & 4967 \\
\hline 21 & 37.00 & 3.60 & 1.00 & $35: 65$ & 3.904 & 324289 & 1.465 & 5272 \\
\hline 22 & 30.00 & 3.30 & 1.00 & $35: 65$ & 3.817 & 329942 & 1.432 & 5492 \\
\hline 23 & 30.00 & 3.90 & 1.00 & $35: 65$ & 3.893 & 322270 & 1.551 & 4893 \\
\hline 24 & 30.00 & 3.60 & 0.86 & $35: 65$ & 4.573 & 376226 & 1.495 & 5588 \\
\hline 25 & 30.00 & 3.60 & 1.14 & $35: 65$ & 3.477 & 283145 & 1.452 & 4857 \\
\hline 26 & 30.00 & 3.60 & 1.00 & $35: 65$ & 3.918 & 323553 & 1.485 & 5147 \\
\hline 27 & 30.00 & 3.60 & 1.00 & $35: 65$ & 3.928 & 324240 & 1.488 & 5153 \\
\hline 28 & 30.00 & 3.60 & 1.00 & $35: 65$ & 3.931 & 322830 & 1.486 & 5191 \\
\hline 29 & 30.00 & 3.60 & 1.00 & $35: 65$ & 3.929 & 322545 & 1.482 & 5194 \\
\hline 30 & 30.00 & 3.60 & 1.00 & $35: 65$ & 3.930 & 323796 & 1.484 & 5180 \\
\hline
\end{tabular}

Software suggested experiments were executed, and responses were collected and entered in the software for their statistical analysis and optimization.

At the time of optimization of other factors were fixed continual such as wavelength, oven temperature, column and injection volume. The wavelength for detection of LTG in samples was fixed at $256 \mathrm{~nm}$, oven temperature was adjusted at $25^{\circ} \mathrm{C}$, injection volume was fixed to $20 \mu \mathrm{L}$ and HyperClone (Phenomenex $\left.{ }^{\circledR}\right) \mathrm{C}_{18}(250 \mathrm{~mm} \times 4.6 \mathrm{~mm}$ i.d, $5 \mu \mathrm{m}$, BDS $130 \AA$ ) with security guard precolumn (Phenomenex $\left.{ }^{\circledR}\right) \mathrm{C}_{18}(4.0 \times 3.0 \mathrm{~mm}$ i.d) used was stationary phase. 


\section{Verification of optimized chromatographic conditions}

Variables were optimized based on the requirement. Optimized chromatographic conditions were verified by performing the experiment. The responses obtained from the experiment were compared with optimized responses (software predicted responses).

\section{Validation of developed analytical method}

Newly developed HPLC method for estimation of LTG in samples was validated as per the "International Council for Harmonization of Technical Requirements for Pharmaceuticals for Human Use (ICH) guidelines for analytical method development and validation" [21].

\section{Specificity}

It is executed to confirm the absence of mobile phase intrusion on LTG peak. It was accomplished by injecting three individual injections of blank and three individual injections of $10 \mu \mathrm{g} / \mathrm{mL}$ LTG in HPLC [16,21].

\section{System suitability}

Study was executed by injecting three individual injections of $10 \mu \mathrm{g} / \mathrm{mL}$ LTG concentration in HPLC. The system suitability was established by gaging and comparing the number of theoretical plates, tailing factor at 5\% and peak area values with acceptable limits of ICH [21].

\section{Linearity}

The calibration curve was constructed using eight different concentrations for LTG in the range of 1 to $22 \mu \mathrm{g} / \mathrm{mL}$. Each concentration was analysed in triplicate. The regression equation and coefficient of determination was computed from the obtained peak area and respective concentrations [21]. Furthermore, the average intercept and slope values were calculated from three calibration curves and were confirmed with their confidence interval.

\section{Precision}

It comprises of two interday precision and intraday precision. Both precision studies were executed for three concentrations viz., 1,11 , and $22 \mu \mathrm{g} / \mathrm{mL}$. The intraday precision was calculated by injecting six individual injections of each concentration of LTG in the morning and six individual injections in evening on the same day. Interday precision was calculated by injecting six individual injections of each concentration of LTG on first day and six individual injections of each concentration of LTG on the next day on the same time. Interday and intraday precisions were established by calculating and comparing the percent relative standard deviation values with acceptable criteria of ICH [21].

\section{Recovery}

Recovery of analytical method expresses the accuracy of method as it shows the closeness of test values and actual values found. Percent recovery values were assessed at three different levels viz., $75 \%, 100 \%$ and $125 \%$ of LTG [20,22]. The obtained results were compared with official assay limits of LTG.

\section{Limit of detection (LOD) and limit of quantification ( $L O Q)$}

LOD and LOQ were designed to estimate the sensitivity of developed HPLC method. LOD and LOQ values were calculated as per the ICH guidelines by using mean standard deviation of response and slope of calibration curve [16,23]. LOD and LOQ were assessed by using the below given relations:

$$
\begin{aligned}
& \mathrm{LOD}=3.3 \mathrm{\sigma} / \mathrm{s} \\
& \mathrm{LOQ}=10 \mathrm{\sigma} / \mathrm{s}
\end{aligned}
$$

where, $\sigma=$ standard deviation of the response and $\mathrm{s}=$ slope value obtained from the calibration curve. 


\section{Application of developed HPLC method for estimation of lamotrigine in lipid nanoformulations}

LTG loaded lipid nanoparticles was prepared by hot microemulsion ultrasonication technique using glyceryl monostearate as lipid and poloxamer 188 as a stabilizer. Entrapment efficiency of prepared lipid nanoparticles was determined using nanosep. Lipid nanoformulation of LTG was taken in nanosep and was centrifuged at 10,000 rpm for $10 \mathrm{~min}$. Filtrate was collected and analysed in triplicate using developed HPLC method. The percent entrapment efficiency of LTG loaded lipid nanoformulation was calculated using the below given formula [24]:

$$
\text { Encapsuation efficiency }(\%)=\frac{\text { Total drug }- \text { Free drug }}{\text { Total drug }} \times 100
$$

\section{Results and discussions}

A full 4-factor-2-level CCD design was employed to investigate the interaction between variables viz., strength of buffer, $p \mathrm{H}$ of buffer, flow rate and mobile phase ratio. $\mathrm{CCD}$ is considered to be the most precise and efficient design for optimization with satisfactory number of experiments [25]. A full CCD design with four factors suggested total 30 experiments in this study and all the experiments were executed as per the software suggested chromatographic conditions and the responses were gained from the experiments (as portrayed in Table 3) were entered in the software.

Data entered in the software was analysed by applying analysis of variance (ANOVA) and polynomial equations were engendered. ANOVA endorsed the results are significant if the probability level $\mathrm{p}<5 \%(\mathrm{p}<0.05)$. Table 4 exemplifying the probable effect of variables on responses and $\mathrm{p}$-value found from ANOVA. The positive values of coefficient estimate are obvious for the synergistic effect whereas negative values of coefficient estimate are evident for the opposite effect of variables on responses. The general polynomial equation for quadratic model is given below:

$$
\begin{gathered}
\mathrm{R}=\beta_{0}+\beta_{1} \mathrm{~A}+\beta_{2} \mathrm{~B}+\beta_{3} \mathrm{C}+\beta_{4} \mathrm{D}+\beta_{12} \mathrm{AB}+\beta_{13} \mathrm{AC}+\beta_{14} \mathrm{AD}+\beta_{23} \mathrm{BC}+\beta_{24} \mathrm{BD}+ \\
+\beta_{34} \mathrm{CD}+\beta_{11} \mathrm{~A}^{2}+\beta_{22} \mathrm{~B}^{2}+\beta_{33} \mathrm{C}^{2}+\beta_{44} \mathrm{D}^{2}
\end{gathered}
$$

Where, $\mathrm{R}$ is the measured response associated with each variable and level combination; $\beta_{0}$ is constant; $\beta_{1}, \beta_{2}, \beta_{3}$ are linear coefficients represents main effect of variables, $\beta_{12}, \beta_{13}$ and $\beta_{23}$ are interactive coefficients denotes interactive effect between four variables, $\beta_{11}, \beta_{22}, \beta_{33}$ and $\beta_{44}$ are quadratic coefficients. A, B, C and D designates strength of buffer, $\mathrm{pH}$ of buffer, flow rate and mobile phase composition, respectively. The terms $\mathrm{AB}, \mathrm{AC}, \mathrm{AD}, \mathrm{BC}, \mathrm{BD}$ and $\mathrm{CD}$ exemplify the interaction between the variables.

Under statistical analysis (as articulated in Table 4), strength of buffer (A), flow rate (C), and mobile phase composition (D) revealed negative significant $(\mathrm{p}<0.001)$ effect on LTG tailing factor whereas $p \mathrm{H}$ of buffer $(\mathrm{B})$ signified positive significant $(\mathrm{p}<0.001)$ effect on LTG tailing factor. Interactive variables (like $\mathrm{AB}, \mathrm{AC}, \mathrm{BC}, \mathrm{CD}$ ) and quadratic terms (like $\mathrm{A}^{2}$ and $\mathrm{B}^{2}$ ) did not exhibited any significant effect $(p>0.05)$ on tailing factor [16]. Only two interactive variables such as AD and BD displayed positive significant $(\mathrm{p}<0.05)$ and negative significant $(\mathrm{p}<0.05)$ effect, respectively on tailing factor. Polynomial equation for tailing factor was generated as given below to study the effect of variables:

Tailing factor $\left(\mathrm{R}_{1}\right)=1.491633333-0.024821429 \mathrm{~A}+0.046833333 \mathrm{~B}-0.016440233 \mathrm{C}-0.0069 \mathrm{D}-$ $0.005940233 \mathrm{AB}-0.004416667 \mathrm{AC}+0.004684343 \mathrm{AD}+0.002428571 \mathrm{BC}-0.007441176 \mathrm{BD}-$ $0.000381282 \mathrm{CD}+0.00342 \mathrm{~A}^{2}-0.00183 \mathrm{~B}^{2}-0.00417 \mathrm{C}^{2}$.

Furthermore, the effect of variables on tailing factor was also inveterate with the help of perturbation and 3D response surface plots. Figure 1(b), 2(a) and 2(b) illustrating the effect of variables on tailing factor. Perturbation plot (Figure 1(b)) confirmed that the $\mathrm{pH}$ of buffer (B) is responsible for increasing the tailing factor of LTG peak whereas the strength of buffer (A) and flow rate (C) are obliging to decease the tailing factor of LTG peak. These results are parallel to the effect 
of $p \mathrm{H}$ of buffer and flow rate on tailing factor of valsartan peak [16]. 3D response surface plot (Figure 2(a) and 2(b)) also inveterate the same effect of $p \mathrm{H}$ of buffer, strength of buffer and flow rate on tailing factor of LTG.

Table 4. Statistical ANOVA of responses

\begin{tabular}{|c|c|c|c|c|c|c|c|c|}
\hline \multirow[t]{2}{*}{ Factors } & \multicolumn{2}{|c|}{ Tailing factor } & \multicolumn{2}{|c|}{ Peak area } & \multicolumn{2}{|c|}{ Retention time } & \multicolumn{2}{|c|}{ NTP } \\
\hline & $\begin{array}{l}\text { Coefficient } \\
\text { Estimate }\end{array}$ & p-value & $\begin{array}{c}\text { Coefficient } \\
\text { Estimate }\end{array}$ & p-value & $\begin{array}{c}\text { Coefficient } \\
\text { Estimate }\end{array}$ & p-value & $\begin{array}{c}\text { Coefficient } \\
\text { Estimate }\end{array}$ & p-value \\
\hline A & -0.025 & $<0.0001$ & 1340.00 & 0.1246 & 0.015 & 0.4737 & 119.64 & $<0.0001$ \\
\hline B & 0.047 & $<0.0001$ & -1607.50 & 0.057 & 0.045 & 0.033 & -246.00 & $<0.0001$ \\
\hline $\mathrm{C}$ & -0.016 & $<0.0001$ & -33577.67 & $<0.0001$ & -0.51 & $\begin{array}{c}< \\
0.0001\end{array}$ & -239.71 & $<0.0001$ \\
\hline $\mathrm{D}$ & $-6.900 \mathrm{E}-003$ & 0.0003 & 1543.83 & 0.0021 & -1.26 & $\begin{array}{c}< \\
0.0001\end{array}$ & -524.23 & $<0.0001$ \\
\hline $\mathrm{AB}$ & $-5.940 \mathrm{E}-003$ & 0.1703 & -1112.42 & 0.3509 & -0.037 & 0.2175 & 36.92 & 0.0467 \\
\hline $\mathrm{AC}$ & $-4.417 \mathrm{E}-003$ & 0.2883 & 214.00 & 0.8515 & -0.055 & 0.0674 & -17.13 & 0.3187 \\
\hline $\mathrm{AD}$ & $4.684 \mathrm{E}-003$ & 0.0386 & -292.50 & 0.6219 & $7.449 \mathrm{E}-003$ & 0.6157 & -6.25 & 0.4781 \\
\hline$\overline{B C}$ & $2.429 \mathrm{E}-003$ & 0.5673 & 2190.00 & 0.0781 & 0.099 & 0.0038 & 71.02 & 0.0008 \\
\hline $\mathrm{BD}$ & $-7.441 \mathrm{E}-003$ & 0.0019 & -1048.15 & 0.0804 & -0.033 & 0.0320 & 36.59 & 0.0004 \\
\hline $\mathrm{CD}$ & $-3.813 \mathrm{E}-004$ & 0.8561 & 296.78 & 0.6151 & 0.11 & $\begin{array}{c}< \\
0.0001\end{array}$ & -3.43 & 0.6939 \\
\hline $\mathrm{A}^{2}$ & $3.420 \mathrm{E}-003$ & 0.1298 & -204.17 & 0.7377 & -0.025 & 0.1110 & -33.31 & 0.0017 \\
\hline $\mathrm{B}^{2}$ & $-1.833 \mathrm{E}-003$ & 0.3551 & -441.85 & 0.4241 & -0.069 & 0.0001 & 13.42 & 0.1115 \\
\hline $\mathrm{C}^{2}$ & $-4.174 \mathrm{E}-003$ & $<0.0001$ & 3002.86 & 0.0001 & 0.060 & 0.0009 & 44.15 & 0.0001 \\
\hline$\overline{R-S q u a r e}$ & \multicolumn{2}{|c|}{0.9814} & \multicolumn{2}{|c|}{0.9952} & \multicolumn{2}{|c|}{0.9990} & \multicolumn{2}{|c|}{0.9982} \\
\hline $\begin{array}{l}\text { Adj R- } \\
\text { Square }\end{array}$ & \multicolumn{2}{|c|}{0.9663} & \multicolumn{2}{|c|}{0.9913} & \multicolumn{2}{|c|}{0.9981} & \multicolumn{2}{|c|}{0.9968} \\
\hline $\begin{array}{l}\text { Pred R- } \\
\text { Square }\end{array}$ & \multicolumn{2}{|c|}{0.8790} & \multicolumn{2}{|c|}{0.9677} & \multicolumn{2}{|c|}{0.9930} & \multicolumn{2}{|c|}{0.9898} \\
\hline Adeq Pre & \multicolumn{2}{|c|}{32.065} & \multicolumn{2}{|c|}{62.002} & \multicolumn{2}{|c|}{102.904} & \multicolumn{2}{|c|}{87.495} \\
\hline
\end{tabular}

Abbreviations- A- Strength of buffer, B-pH of buffer, C-Flow rate, D-Mobile phase composition, NTP- number of theoretical plates.

As shown in Table 4, strength of buffer (A) and $p \mathrm{H}$ of buffer (B) did not showed any significant ( $>0.05$ ) effect on peak area of LTG whereas flow rate (C) and mobile phase composition (D) exemplified negative significant and positive significant effect, respectively on peak area of LTG. All the variables exhibited non-significant ( $\mathrm{p}>0.05$ ) interactive effect (such as $\mathrm{AB}, \mathrm{AC}, \mathrm{AD}, \mathrm{BC}, \mathrm{BD}$ and CD) on LTG peak area [26]. Similarly, all the variables displayed non-significant ( $>0.05)$ quadratic effect (such as $\mathrm{A}^{2}$ and $\mathrm{B}^{2}$ ) on LTG peak area except flow rate (as $\mathrm{C}^{2}$ ) which demonstrated positive significant $(\mathrm{p}<0.001)$ effect on peak area. Polynomial equation for LTG peak area was produced as specified below to study the effect of variables:

Peak area $\left(R_{2}\right)=322421.1+1340 \mathrm{~A}-1607.5 \mathrm{~B}-33577.7 \mathrm{C}+1543.833 \mathrm{D}-1112.42 \mathrm{AB}+214 \mathrm{AC}-$ $292.5 \mathrm{AD}+2190 \mathrm{BC}-1048.15 \mathrm{BD}+296.7847 \mathrm{CD}-204.171 \mathrm{~A}^{2}+441.853 \mathrm{~B}^{2}+3002.863 \mathrm{C}^{2}$.

Further, the effect of variables on peak area was verified with perturbation and $3 \mathrm{D}$ response surface plots. Figure 1(c), 2(c) and 2(d) demonstrating the effect of variables on LTG peak area. Perturbation plot (Figure 1(c)) confirmed that the flow rate $(\mathrm{C})$ is responsible for decreasing the peak area of LTG whereas strength of buffer (A) and $p \mathrm{H}$ of buffer (B) does not produce any effect on peak area. The decrease in peak area with increase in flow rate may be due to decrease in retention time and that is reducing resolution of the LTG peak. These results are parallel in the line to the effect of $p \mathrm{H}$ of buffer (B) and flow rate (C) on peak area of valsartan [16]. 3D response surface plot (Figure 2(c) and 2(d)) also confirmed the effect of strength of buffer, $p \mathrm{H}$ of buffer and flow rate on LTG peak area. 

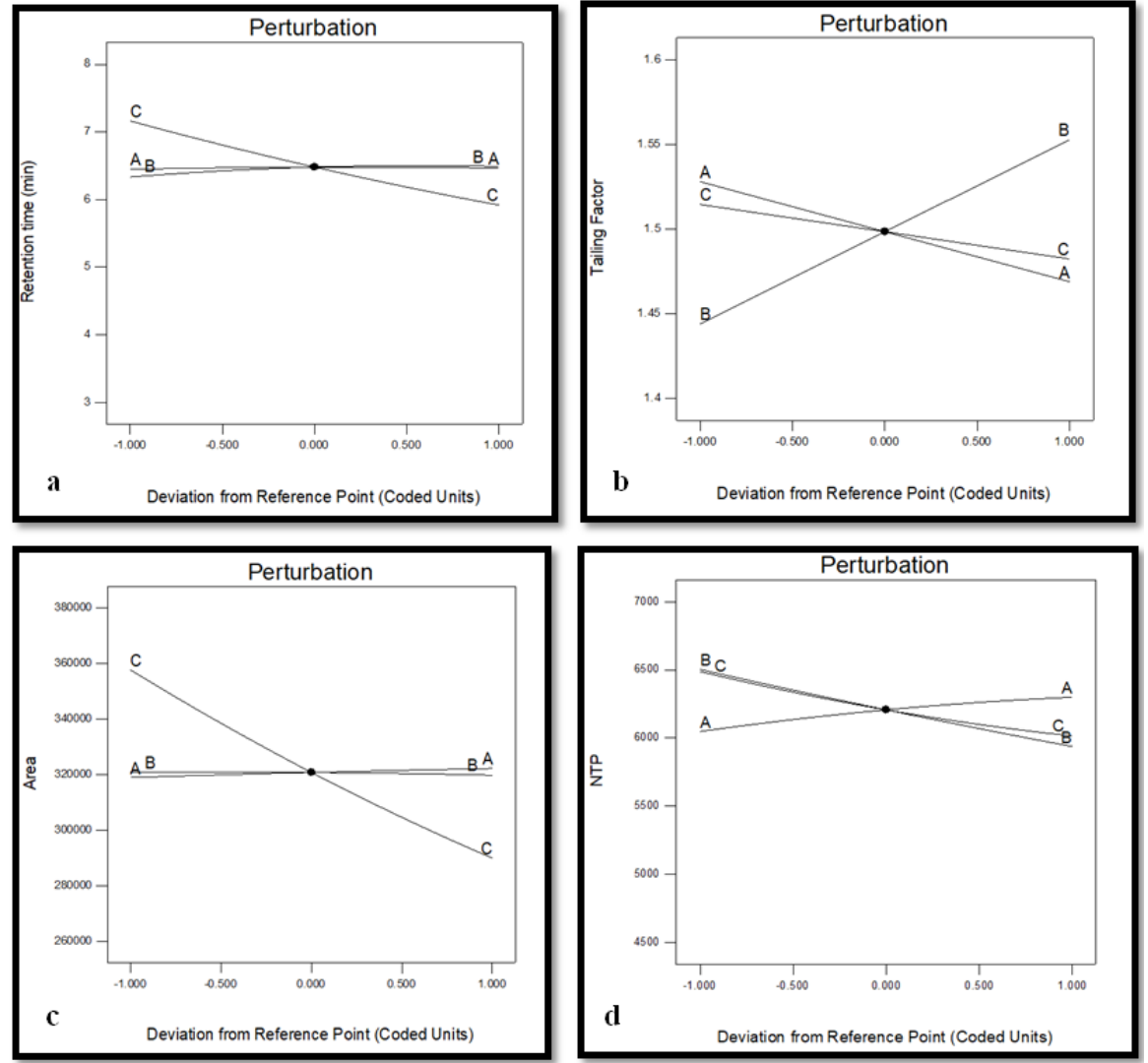

Figure 1. Perturbation plots demonstrating effect of variables.

Abbreviations- A- Strength of buffer, B- $p \mathrm{H}$ of buffer and C-Flow rate

Results attained from statistical analysis (specified in Table 4) revealed significant effect $(\mathrm{p}<0.05)$ of $p \mathrm{H}$ of buffer (B), flow rate (C) and mobile phase composition (D) on retention time whereas strength of buffer (D) exhibited non-significant effect ( $p>0.05)$ on LTG retention time. Some variables illustrated non-significant ( $\mathrm{p}>0.05$ ) interactive (viz., $\mathrm{AB}, \mathrm{AC}$ and $\mathrm{AD}$ ) as well as quadratic (viz., $\mathrm{A}^{2}$ ) effect on retention time. Few variables exhibited positive significant $(\mathrm{p}<0.001)$ interactive (viz., $\mathrm{BC}$ and $\mathrm{CD}$ ) and quadratic (viz., $\mathrm{C}^{2}$ ) effect on retention time whereas $p \mathrm{H}$ of buffer and mobile phase composition displayed negative significant $(\mathrm{p}<0.05)$ interactive effect $(\mathrm{BD})$ and $p \mathrm{H}$ of buffer also showed negative significant $(\mathrm{p}<0.001)$ quadratic $\left(\mathrm{B}^{2}\right)$ effect on LTG retention time.

Polynomial equation for LTG retention time was formed as detailed below to study the effect of variables: 

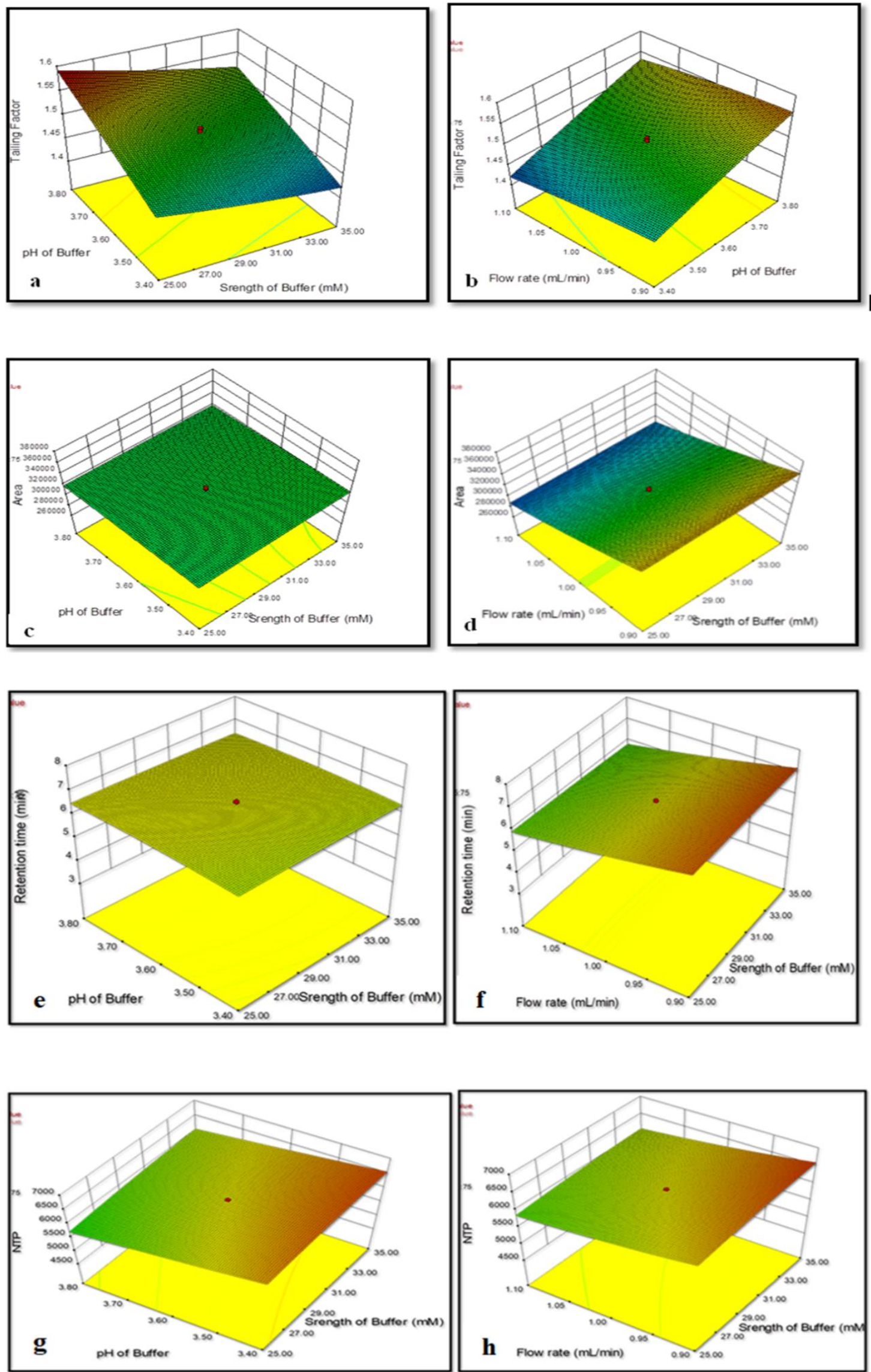

Figure 2. 3D response surface plots illustrating effect of variables on responses 
Retention time $\left(\mathrm{R}_{3}\right)=5.217105+0.015179 \mathrm{~A}+0.044667 \mathrm{~B}-0.5123 \mathrm{C}-1.26443 \mathrm{D}-0.03717 \mathrm{AB}-$ $0.05521 \mathrm{AC}+0.007449 \mathrm{AD}+0.098554 \mathrm{BC}-0.033 \mathrm{BD}+0.109715 \mathrm{CD}-0.02528 \mathrm{~A}^{2}-0.06915 \mathrm{~B}^{2}+$ $0.060365 \mathrm{C}^{2}$.

Besides, the effect of variables on retention time was verified with perturbation and 3D response surface plots. Figure 1(a), 2(e) and 2(f) representing the effect of variables on LTG retention time. Perturbation plot (Figure 1(a)) inveterate that the flow rate $(\mathrm{C})$ is accountable for reducing the retention time of LTG whereas strength of buffer (A) and $p \mathrm{H}$ of buffer (B) exhibited very trivial effect on retention time of LTG. 3D response surface plot (Figure 2(e) and 2(f)) also confirmed the similar effect of strength of buffer, $p \mathrm{H}$ of buffer and flow rate on LTG retention time.

Statistical analysis (detailed in Table 4) revealed negative significant $(\mathrm{p}<0.0001)$ effect of $p \mathrm{H}$ of buffer (B), flow rate (C) and mobile phase composition (D) on NTP, however strength of buffer (D) displayed positive significant $(\mathrm{p}<0.0001)$ effect on NTP of LTG. Few variables demonstrated nonsignificant ( $\mathrm{p}>0.05)$ interactive effect (viz., $\mathrm{AC}, \mathrm{AD}$ and $\mathrm{CD})$ and quadratic effect (viz., $\mathrm{B}^{2}$ ) on NPT. Few variables showed positive significant $(\mathrm{p}<0.001)$ interactive effect (viz., $\mathrm{AB}, \mathrm{BC}$ and $\mathrm{BD})$ and quadratic effect $\left(v i z ., C^{2}\right)$ on NTP whereas strength of buffer exhibited negative significant $(\mathrm{p}<0.001)$ quadratic effect $\left(\mathrm{A}^{2}\right)$ on NTP. Polynomial equation for NTP was formed as detailed below to study the effect of variables:

Number of theoretical plates $(\mathrm{NTP})\left(\mathrm{R}_{4}\right)=5683.536+119.6429 \mathrm{~A}-246 \mathrm{~B}-239.709 \mathrm{C}-524.233 \mathrm{D}+$ $36.9158 \mathrm{AB}-17.125 \mathrm{AC}-6.25 \mathrm{AD}+71.01786 \mathrm{BC}+36.58824 \mathrm{BD}-3.43166 \mathrm{CD}-33.3073 \mathrm{~A}^{2}+$ $13.42246 B^{2}+44.14627 C^{2}$.

Besides, the effect of variables on NTP was proved with perturbation and 3D response surface plots. Figure 1(d), 2(g) and 2(h) presenting the effect of variables on NTP. Perturbation plot (Figure 1(a)) confirmed that the $p \mathrm{H}$ of buffer (B) and flow rate (C) are liable for dropping the NTP whereas strength of buffer (A) is accountable for increasing NTP. 3D response surface plot (Figure 2(e) and 2(f)) also inveterate the comparable effect of strength of buffer, $p \mathrm{H}$ of buffer and flow rate on NTP.

The concluding optimized chromatographic conditions are depicted in Table 5. Responses attained after execution of experiment are displayed in Table 6. As exposed in Table 6, the residual values are found to be less than $4 \%$. Hence, the results are powerfully endorsing the correlation between the responses gained after execution of experiment and software projected responses.

The chromatograms of blank and $10 \mu \mathrm{g} / \mathrm{mL}$ of LTG are displayed in Figure 3. As illustrated in Figure 3, LTG was eluted at $3.844 \mathrm{~min}$. It inveterate the absence of intrusion on LTG peak from mobile phase.

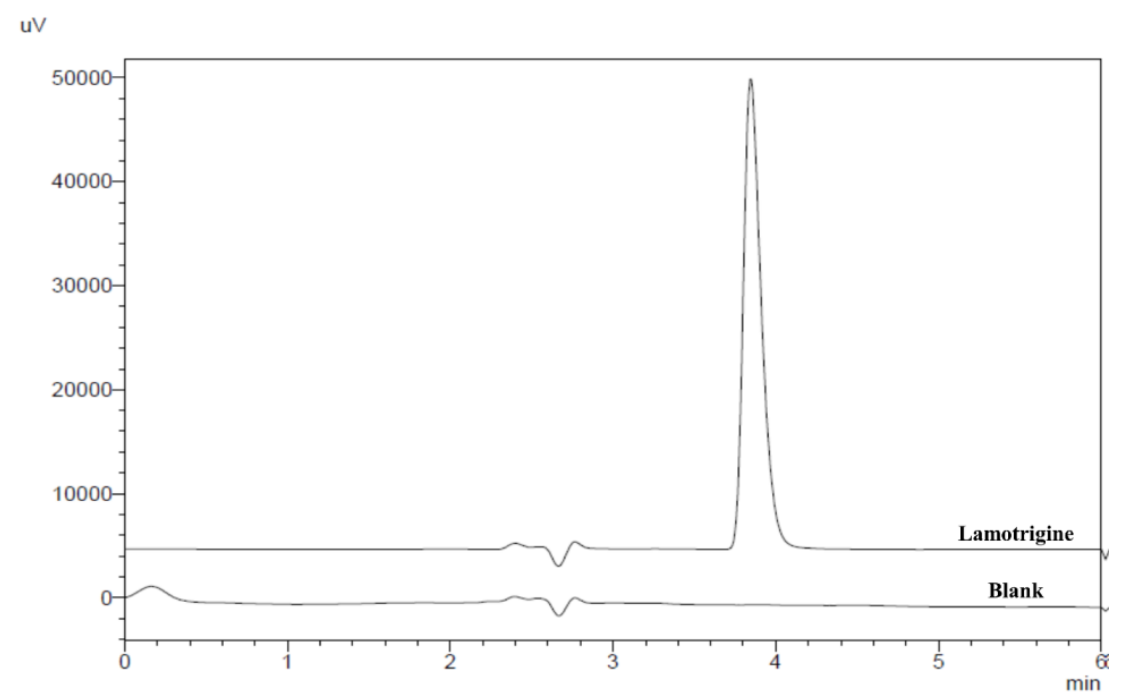

Figure 3. HPLC chromatogram of $10 \mu \mathrm{g} / \mathrm{mL}$ lamotrigine and blank 
Table 5. Optimized chromatographic conditions

\begin{tabular}{|c|c|c|c|c|c|c|c|c|}
\hline $\begin{array}{l}\text { S. } \\
\text { No. }\end{array}$ & Stationary phase & $\begin{array}{l}\text { Buffer } \\
\text { strength } \\
\text { (mM) }\end{array}$ & $\begin{array}{l}\text { pH of } \\
\text { buffer }\end{array}$ & $\begin{array}{l}\text { Mobile phase } \\
\text { composition } \\
(\% \mathrm{v} / \mathrm{v})\end{array}$ & $\begin{array}{l}\text { Detection } \\
\text { wavelength } \\
\text { (nm) }\end{array}$ & $\begin{array}{l}\text { Injection } \\
\text { volume } \\
(\mu \mathrm{L})\end{array}$ & $\begin{array}{c}\text { Flow rate } \\
(\mathrm{mL} / \mathrm{min})\end{array}$ & $\begin{array}{l}\text { Oven } \\
\text { temperature } \\
\left({ }^{\circ} \mathrm{C}\right)\end{array}$ \\
\hline 1. & $\begin{array}{l}\text { HyperClone } \\
\left(\text { Phenomenex }{ }^{\circledR}\right) \\
\mathrm{C}_{18}(250 \mathrm{~mm} \times \\
4.6 \mathrm{~mm} \text { i.d, } 5 \mu \mathrm{m} \text {, } \\
\text { BDS } 130 \AA)\end{array}$ & 35 & 3.5 & $\begin{array}{l}\text { Acetonitrile: } \\
\text { ammonium } \\
\text { formate buffer } \\
(35: 65)\end{array}$ & 265 & 20 & 1.0 & 25 \\
\hline
\end{tabular}

Percent residual standard deviation (\%RSD) values of peak area, tailing factor, retention time and number of theoretical plates were found to be $0.15,0.16,0.05$ and 0.42 , respectively. The found results are showing the developed HPLC method is suitable.

Calibration curve of LTG was built in the array of 1 to $22 \mu \mathrm{g} / \mathrm{mL}$ using the average peak area of three trials as represented in Figure 4. The coefficient of determination $\left(\mathrm{r}^{2}\right)$ and regression equation from the built calibration plot were found to be 0.9982 and $y=34854 x+14083$, respectively.

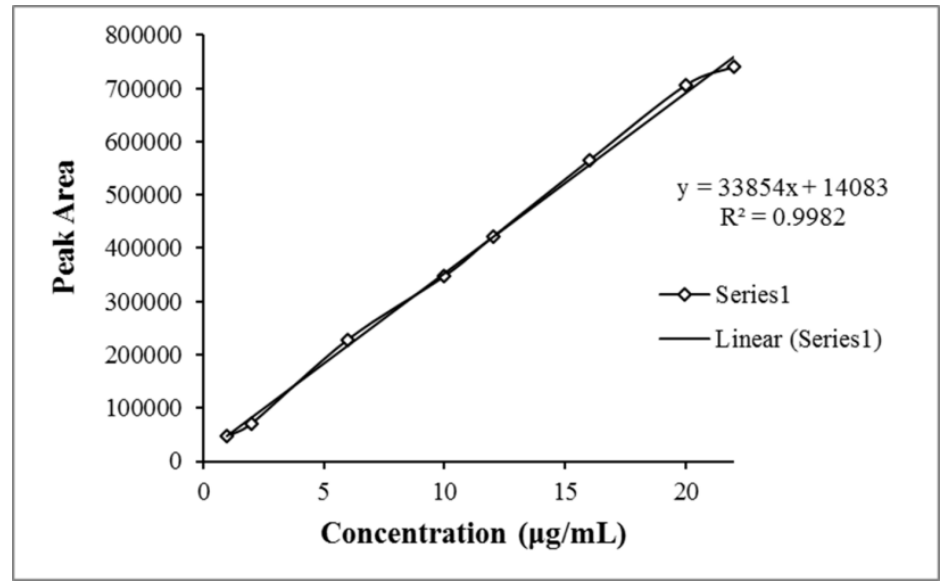

Figure 4. Calibration curve of lamotrigine constructed from the average peak area of three trials

Table 6. Responses of optimized formula with percent residual values

\begin{tabular}{|l|l|l|l|}
\hline Responses & $\begin{array}{l}\text { Software suggested } \\
\text { values }\end{array}$ & $\begin{array}{l}\text { Actual observed } \\
\text { values* }\end{array}$ & $\begin{array}{l}\text { Residual values } \\
(\%)\end{array}$ \\
\hline Peak area (uV) & 335254.25 & $347408 \pm 505.45$ & -3.63 \\
\hline Tailing factor & 1.45 & $1.423 \pm 0.002$ & 1.86 \\
\hline Retention time (min) & 4.000 & $3.844 \pm 0.002$ & 3.90 \\
\hline Number of theoretical plates (NTP) & 5440.98 & $5292 \pm 22.27$ & 2.74 \\
\hline
\end{tabular}

*Data is specified as Mean $\pm \mathrm{SD}, \mathrm{n}=3$.

The coefficient of determination value is more towards 1.0 which is reflecting strong correlation between LTG concentration and peak area. The average intercept and slope values were found to be $14082.67 \pm 327.24$ and $33854.00 \pm 12.53$, respectively. All the obtained results were found to be within the acceptance criteria at $95 \%$ confidence interval i.e. between 13712.35 - 14452.98 and $33839.82-33868.18$ for intercept and slope, respectively.

Interday and intraday precision results are conveyed in Table 7. Interday and intraday results are found to be well within the acceptable criteria of ICH guidelines for analytical method development and validation [20]. The results approved that the developed method is precise and can be used for LTG estimation in nanoformulations. 
Table 7. Interday and intraday precision

\begin{tabular}{|l|l|l|l|l|l|l|}
\hline \multirow{2}{*}{$\begin{array}{c}\text { Conc. } \\
(\boldsymbol{\mu g} / \mathbf{m L})\end{array}$} & \multicolumn{2}{|l|}{ Intraday precision } & \multicolumn{3}{l|}{ Interday precision } \\
\cline { 2 - 7 } & Mean & SD & \%RSD & Mean & SD & \%RSD \\
\hline 1 & 48632.08 & 286.97 & 0.59 & 48688.42 & 349.74 & 0.72 \\
\hline 11 & 390099.80 & 664.26 & 0.17 & 391156.00 & 1322.11 & 0.34 \\
\hline 22 & 741598.60 & 1608.32 & 0.22 & 744866.90 & 4923.63 & 0.66 \\
\hline
\end{tabular}

Abbreviations: RSD - Relative standard deviation; and SD - Standard deviation.

The study was performed at three different levels such as 75,100 and $125 \%$. The percent recovery values for 75,100 and $125 \%$ were found to be $101.98 \pm 0.21,100.67 \pm 0.12$ and $97.16 \pm 0.05 \%$, respectively. All the obtained individual percent recovery values for 75,100 and $125 \%$ were found to be within the acceptance range at $95 \%$ confidence interval i.e. between 101.74 to $102.21 \%, 100.53$ to $100.81 \%$ and 97.11 to $97.22 \%$, respectively. The found results are demonstrating that the method can give consistent recovery.

LOD and LOQ values were found to be 9.07 and $27.48 \mathrm{ng} / \mathrm{mL}$, respectively. The values shown that the developed HPLC method is sensitive and can be used for analysis of LTG in nanoformulations.

LTG loaded lipid nanoparticles were characterized for mean particle size, polydispersity index (PDI), zeta potential values and entrapment efficiency. The mean particle size, PDI and zeta potential values of optimized LTG loaded nanoformulation was found to be $563.80 \mathrm{~nm}, 0.725$ and $-45.20 \mathrm{mV}$, respectively. The entrapment efficiency of prepared LTG loaded lipid nanoformulation was found to be $73.44 \pm 6.65 \%$ by analysis with developed HPLC method. The obtained results of individual entrapment efficiency were found to be within the acceptance limits at $95 \%$ confidence interval i.e. between 65.91 to $80.97 \%$.

\section{Conclusions}

In the current study, RP-HPLC-UV method was developed using CCD for the estimation of lamotrigine in lipid nanoformulation. The developed HPLC method was validated successfully as per the ICH Q2(R1) guidelines and found that the developed HPLC method is simple, precise, sensitive, fast and reproducible. Applications of the developed HPLC method for estimation of drug entrapment in prepared lipid nanoformulation confirms that the developed analytical method is appropriate for estimation of lamotrigine in lipid nanoformulations.

Acknowledgements: Authors are grateful to Dr. Reddy's Laboratories, Hyderabad for providing lamotrigine as a gift sample. Investigators are thankful to Manipal College of Pharmaceutical Sciences, Manipal and Manipal Academy of Higher Education (MAHE), Manipal for providing infrastructural facilities to complete this research work successfully.

\section{References}

1.*** WHO, 2017. WHO | WHO Model Lists of Essential Medicines. WHO, 2017, Available at: http://www.who.int/medicines/publications/essentialmedicines/en/. Accessed on Dec 20, 2018.

2.GANGURDE, P.K., AJITKUMAR, B.N., KUMAR, L., J. Pharm. Innovation., 14, 2019, p. 91.

3.GOLDBERG, J.F., CALABRESE, J.R., SAVILLE, B.R., FRYE, M.A., KETTER, T.A., SUPPES, T., POST, R.M., GOODWIN, F.K., J. Clin. Psychiatry., 70, 2009, p. 1273.

4.EMAMI, J., GHASSAMI, N., AHMADI, F., J. Pharm. Biomed. Anal., 40, 4, 2006, p. 999.

5.GOA, K.L., ROSS, S.R., CHRISP, P., Drugs. 46, 1, 1993, p. 152.

6.CASTEL-BRANCO, M.M., ALMEIDA, A.M., FALCAO, A.C., MACEDO, T.A., CARAMONA, M.M., LOPEZ, F.G., J. Chromatogr. B. Biomed. Sci. Appl., 755, 1-2, 2001, p. 119.

7.SERRALHEIRO, A., ALVES, G., FORTUNA, A., ROCHA, M., FALCAO, A., J. Chromatogr. B., 925, 2013, p. 1.

8.SRIPALAKIT, P., SRICHAIYA, A., KANDEE, R., J. Liq. Chromatogr. Relat. Technol., 31, 6, 2008, p. 926. 
9.JEBABLI, N., GAIES, E., EL JEBARI, H., CHARFI, R., LAKHAL, M., KLOUZ, A., TRABELSI, S., SALOUAGE, I., Tunis Med., 93, 8-9, 2015, p. 565.

10.VERMEIJ, T.A.C., EDELBROEK, P.M., J. Chromatogr. B., 857, 1, 2007, p. 40.

11.PUVVADA, P., MURUGAN, V., KUMAR, S.V., PADARTHI, P.K., Der Pharma Chemica., 2, 1, 2010, p. 104.

12.BARBOSA, N.R., MIIDIO, A.F., J. Chromatogr. B. Biomed. Sci. Appl., 741, 2, 2000, p. 289.

13.PATEL, A., KATARIA, M.K., IJARPB., 2, 2, 2012, p. 95.

14.YOUSSEF, N.F., TAHA, E.A., Chem. Pharm. Bull. (Tokyo), 55, 4, 2007, p. 541.

15.QUEIROZ, M.E.C., CARRILHO, E., CARVALHO, D., LANÇAS, F.M., Chromatographia., 53, 2001, p. 485.

16.KUMAR, L., REDDY, M.S., MANAGULI, R.S., PAI, K.G., Saudi Pharm. J., 23, 2015, p. 549.

17.LINDBERG, N.O., LUNDSTEDT, T., Drug Dev. Ind. Pharm., 21, 9, 1995, p. 987.

18.GANORKAR, S.B., DHUMAL, D.M., SHIRKHEDKAR, A.A., Arab. J. Chem., 10, 2, 2017, p. 273.

19.IULIANI, P., CARLUCCI, G., MARRONE, A., J. Pharm. Biomed. Anal., 51, 1, 2010, p. 46.

20.NAVYA SREE, K.S., PAI, K.G., VERMA, R., ANANTHAKRISHNA, P., KUMAR, L., Pharm. Chem. J., 51, 2, 2017, p. 159.

21.ICH topic Q2(R1), June 1995. Validation of Analytical Procedures: Text and Methodology: ICH. Available from: https://www.ema.europa.eu/en/documents/scientific-guideline/ich-q-2-r1-validationanalytical-procedures-text-methodology-step-5_en.pdf. Accessed June 25, 2019.

22.SHIRODKAR, R.K., KUMAR, L., MISRA, C., MANAGULI, R., ATTARI Z., MTALIK, S., LEWIS, S.A., Lat. Am. J. Pharm., 35, 1, 2016, p. 124.

23.KAZUSAKI, M., UEDA, S., TAKEUCHI, N., OHGAMI, Y., Chromatography., 33, 2, 2012, p. 65. 24.FERNANDES, A.V., PYDI, C.R., VERMA, R., JOSE, J., KUMAR, L., Braz. J. Pharm. Sci. 56, 2020, e18069, p. 1 to 14.

25.PATRAVAlE, V.B., DiSOUZA, J.I., RUSTOMJEE, M., Pharmaceutical Product Development: Insights into Pharmaceutical Processes, Management and Regulatory Affairs. CRC press. 2016.

26.SINGH, S.Y., SALWA, SHIRODKAR, R.K., VERMA, R., KUMAR, R., J Pharm Innovation. In Press. https://doi.org/10.1007/s12247-019-09397-1.

$\overline{\text { Manuscript received: } 12.11 .2019}$ 